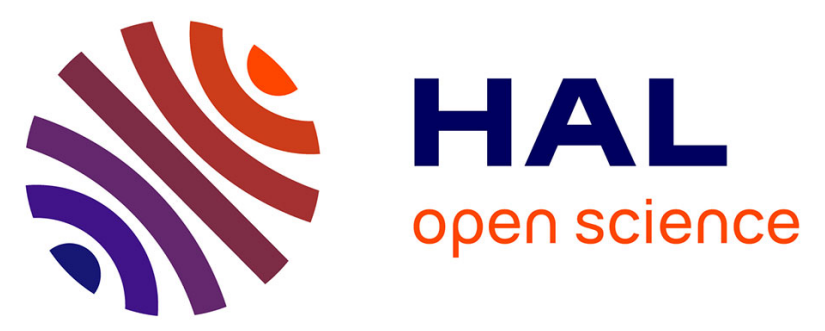

\title{
Addendum to "Late Cenozoic magnetochronology and paleoenvironmental changes in the northern foreland basin of the Tian Shan Mountains" by Jimin Sun, Qinghai $\mathrm{Xu}$, and Baochun Huang
}

Julien Charreau, Jimin Sun, Yan Chen, Stuart A. Gilder, Bochun Huang, Qingchen Wang

\section{To cite this version:}

Julien Charreau, Jimin Sun, Yan Chen, Stuart A. Gilder, Bochun Huang, et al.. Addendum to "Late Cenozoic magnetochronology and paleoenvironmental changes in the northern foreland basin of the Tian Shan Mountains" by Jimin Sun, Qinghai Xu, and Baochun Huang. Journal of Geophysical Research : Solid Earth, 2008, 113, 5 p. 10.1029/2007JB005489 . insu-00310254

\section{HAL Id: insu-00310254 \\ https://hal-insu.archives-ouvertes.fr/insu-00310254}

Submitted on 8 Aug 2008

HAL is a multi-disciplinary open access archive for the deposit and dissemination of scientific research documents, whether they are published or not. The documents may come from teaching and research institutions in France or abroad, or from public or private research centers.
L'archive ouverte pluridisciplinaire HAL, est destinée au dépôt et à la diffusion de documents scientifiques de niveau recherche, publiés ou non, émanant des établissements d'enseignement et de recherche français ou étrangers, des laboratoires publics ou privés. 


\title{
Addendum to "Late Cenozoic magnetochronology and paleoenvironmental changes in the northern foreland basin of the Tian Shan Mountains” by Jimin Sun, Qinghai Xu, and Baochun Huang
}

Julien Charreau : Université d’Orléans, CNRS/INSU, Institut des Sciences de la Terre d'Orléans, , Bâtiment Géosciences, Orléans, France - Now at Division of Geological and Planetary Sciences, California Institute of Technology, Pasadena, California, USA

Jimin Sun : State Key Laboratory of Lithospheric Evolution, Institute of Geology and Geophysics, Chinese Academy of Sciences,

Beijing, China

Yan Chen : Université d'Orléans, CNRS/INSU, Institut des Sciences de la Terre d'Orléans, Bâtiment Géosciences, Orléans, France

Stuart Gilder : Department of Earth and Environmental Sciences, Geophysics Section, Ludwig Maximilians University,

Munich, Germany

Baochun Huang and Qingchen Wang : State Key Laboratory of Lithospheric Evolution, Institute of Geology and Geophysics, Chinese Academy of Sciences,

Beijing, China

\begin{abstract}
Sun et al. (2007) constructed a magnetostratigraphic record of the Kuitun River section (Xinjiang Province, China) and reinterpreted a magnetostratigraphic record from the same section previously published by Charreau et al. (2005). In this paper, we show that Sun et al. miscorrelated their column with respect to that of Charreau et al. A compatible correlation, recognized by both sides, is presented.
\end{abstract}

\section{Introduction}

Numerous studies have been carried out to understand the Tertiary exhumation history of the Tian Shan Mountains in central Asia. One commonly used tool is magnetostratigraphy, which can decipher uplift rates from changes in the deposition rates of the sediments shed from the mountains and deposited in the adjacent foreland basins [e.g., Zheng et al., 2000; Sun et al, 2004; Charreau et al., 2005, 2006; Huang et al., 2006]. At the Dushanzi section on the northern flank of the Tian Shan, Sun et al. [2004] collected 1500 samples over a 1200-mthick profile and dated the section from $\sim 2.5$ to $\sim 8.5 \mathrm{Ma}$. In the Kuitun section, $5 \mathrm{~km}$ east of the Dushanzi section, Charreau et al. [2005] collected 801 samples from a 1559-m-thick section, where 29 magnetic polarity intervals were correlated between $\sim 3.1$ and 10.5 Ma.

Recently, Sun et al. [2007] reinterpreted the published magnetostratigraphic correlation from Kuitun by Charreau et al. [2005]. Sun et al. [2007] collected 176 samples within a 450 m 
span of the same section that Charreau et al. [2005] sampled. Sun et al. [2007] claim that the section they sampled corresponds to the uppermost $400 \mathrm{~m}$ of the Charreau et al. [2005] study. This addendum is intended to clarify sample collection and stratigraphic correlation on the same section.

\section{Stratigraphic Correlation}

[4] On 27 September 2007, both groups visited the Kuitun section together. This visit lead both sides to recognize that (1) the limit between the Xiyu conglomerate and Dushanzi sandstone formation is marked by a change in lithology (Figure 1, top) [see also Sun et al., 2007, Figure 5], (2) the samples collected by Charreau et al. [2005] began at a position $400 \mathrm{~m}$ above this limit then proceeded down section in the Dushanzi sandstones, and (3) the samples collected by Sun et al. [2007] began at a position $50 \mathrm{~m}$ above this limit then proceeded down section. The common observation would therefore introduce a renewed stratigraphic correlation as described below.

The upper $400 \mathrm{~m}$ of the Charreau et al. [2005] section is dominated by coarse conglomerates, interpreted by Charreau et al. [2005, Figure 1] and Sun et al. [2007, Figure 5] to be part of the Xiyu Formation. The massive conglomeratic nature of the sediments severely limited the number of possible horizons for Charreau et al. [2005] to collect oriented samples, which is why their sampling density is so low there $(\sim 0.3 \mathrm{samples} / \mathrm{m})$ (Figure 1$)$. Sun et al. [2007, paragraph 17 and Figure 5] collected their samples, "near the base of the Xiyu Formation down to the Pliocene Dushanzi Formation.” Both studies assign the intercalation of conglomerate, yellow sandstone and brown mudstone to the Dushanzi Formation. This means that the uppermost first $400 \mathrm{~m}$ of Charreau et al.'s section should not be correlated with the Sun et al. [2007] column (Figures 1 and 2) . Appropriately placed in this way, two magnetostratigraphic columns match perfectly (Figure 2).

\section{Discussion}

It remains an open question how to correlate the upper part of Kuitun and Dushanzi magnetostratigraphic column to the reference scale (GPTS) that may introduce an important consequence on climatic and tectonic implications. Two distinct ages are attributed to the basal of the Xiyu Formation, 2.58 Ma by Sun et al. [2004, 2007] and 4.8 Ma by Charreau et al. [2005], respectively. This addendum is only intended to clarify sample collection and stratigraphic correlation on the Kuitun section, rather than to settle all disagreements between the two research groups. The Xiyu conglomerate plays a very important role in understanding Cenozoic tectonic and climatic evolution of central Asia. This addendum brings our two groups to the same cornerstone, and we will continue our effort in study the important issue, although we hold different academic opinion at present. The well-established Kuitun section is potentially an international nature laboratory for Cenozoic tectonic and climatic study, and we have carried out multidisciplinary studies including magnetostratigraphy, sedimentology, U-Th-He dating, organic matters analyses as well as geomorphology and neotectonics. We may offer all detailed differential Global Positioning System (DGPS) measurements to all who wish to study this section. 


\section{Acknowledgments}

The research program has been financed by Chinese project kzcx3-sw-147, French ECLIPSE and ANR (05-Blann-0143-01), and Sino-French PRA project (T05-02/T06-04).

\section{References}

Charreau, J., Y. Chen, S. Gilder, S. Dominguez, J.-P. Avouac, S. Sevket, D. Sun, Y. Li, and W.-M. Wang (2005), Magnetostratigraphy and rock magnetism of the Neogene Kuitunhe section (northwest China): Implications for Late Cenozoic uplift of the Tianshan mountains, Earth Planet. Sci. Lett., 230, 177-192, doi:10.1016/j.epsl.2004.11.002

Charreau, J., S. Gilder, Y. Chen, S. Dominguez, J.-P. Avouac, S. Sen, M. Jolivet, Y. Li, and W. Wang (2006), Magnetostratigraphy of the Yaha section, Tarim Basin (China): $11 \mathrm{Ma}$ acceleration in erosion and uplift of the Tianshan Mountains, Geology, 34, 181-184, doi:10.1130/G22106.1.

Huang, B., J. D. A. Piper, S. Peng, T. Liu, Z. Li, Q. Wang, and R. Zhu (2006), Magnetostratigraphic study of the Kuche Depression, Tarim Basin, and Cenozoic uplift of the Tian Shan Range, western China, Earth Planet. Sci. Lett., 251(3-4), 346-364, doi:10.1016/j.epsl.2006.09.020.

Sun, J., R. Zhu, and J. Bowler (2004), Timing of the Tianshan Mountains uplift constrained by magnetostratigraphic analysis of molasse deposits, Earth Planet. Sci. Lett., 219, 239-253, doi:10.1016/S0012-821X(04)00008-1.

Sun, J., Q. Xu, and B. Huang (2007), Late Cenozoic magnetochronology and paleoenvironmental changes in the northern foreland basin of the Tian Shan Mountains, J. Geophys. Res., 112, B04107, doi:10.1029/2006JB004653.

Zheng, H., C. M. Powell, Z. An, J. Zhou, and G. Dong (2000), Pliocene uplift of the northern Tibetan Plateau, Geology, 28, 715-718, doi:10.1130/0091-

7613(2000)28<715:PUOTNT>2.0.CO;2 


\section{Figures}

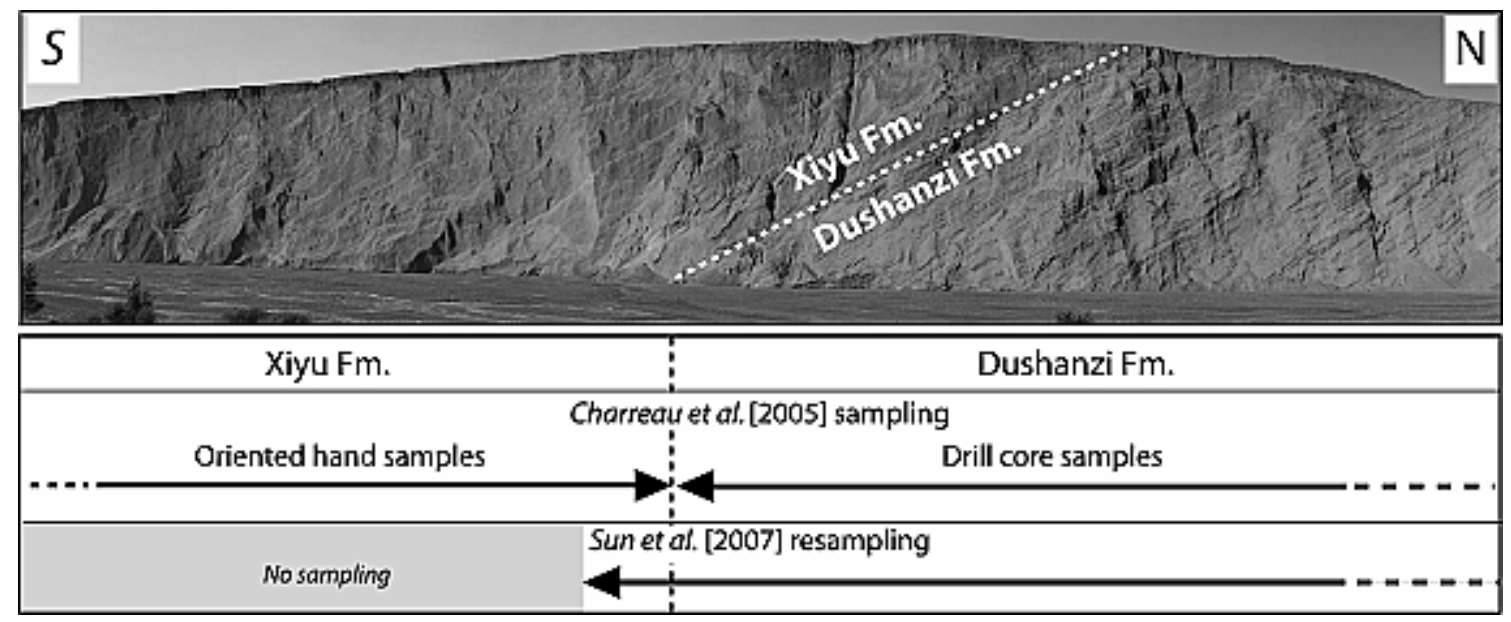

Figure 1. Photograph of the limit between the Xiyu and Dushanzi formations in the Kuitun section with location of our sampling [Charreau et al., 2005] and new sampling of Sun et al. [2007]. The Xiyu/Dushanzi limit lies at $\sim 400 \mathrm{~m}$ in depth on the magnetostratigraphic column of Charreau et al. [2005] (see Figure 2). Above this limit (to the south), in the massive conglomerate, sampling was only possible by hand in select fine-grained lenses, thus giving a lower sampling density. Below this limit (to the north), rocks were amenable for drilling. Enhanced EPS 


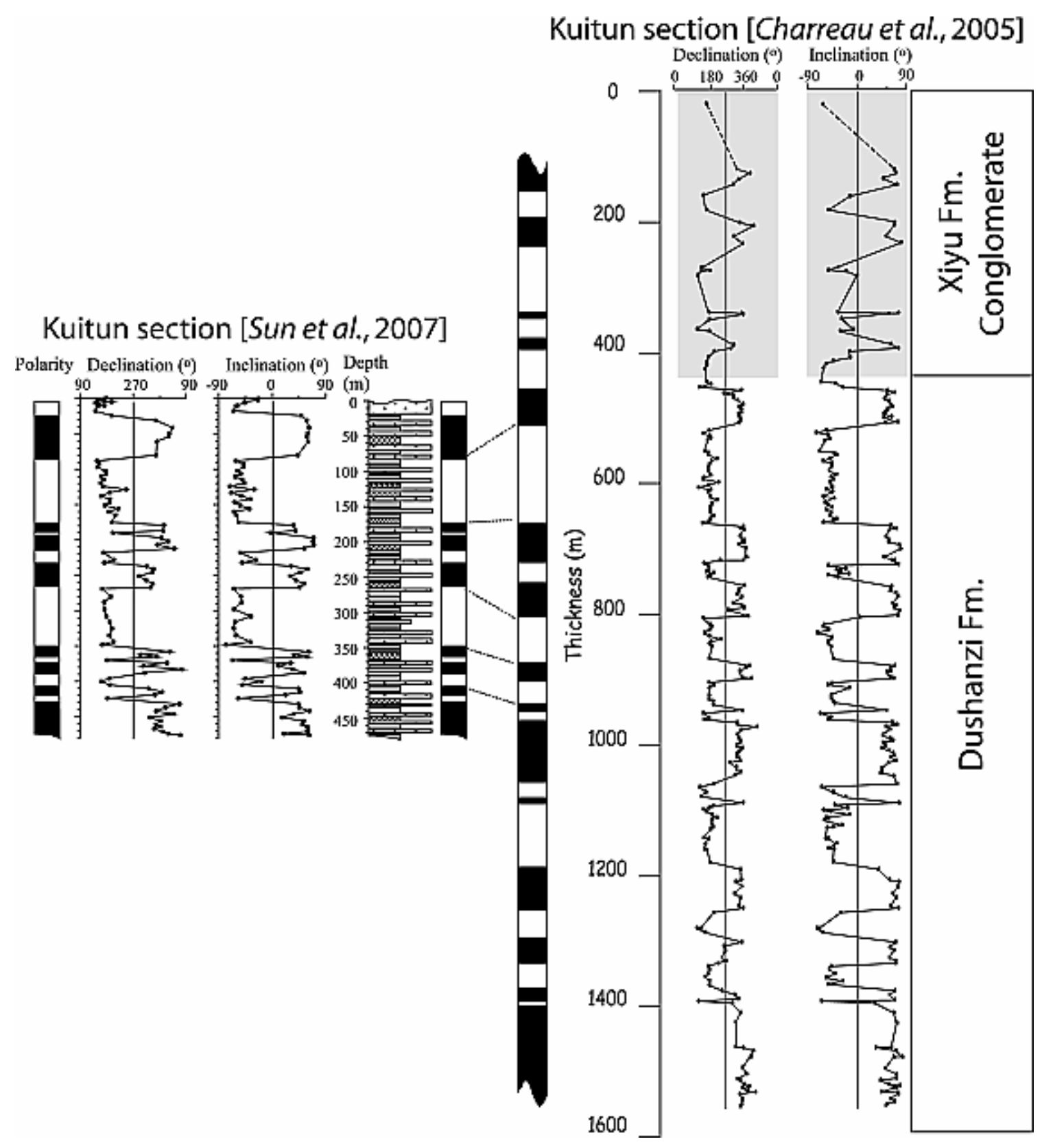

Figure 2. Renewed correlation between the Kuitun magnetostratigraphy column of Sun et al. [2007] and that of Charreau et al. [2005] section. Enhanced EPS 